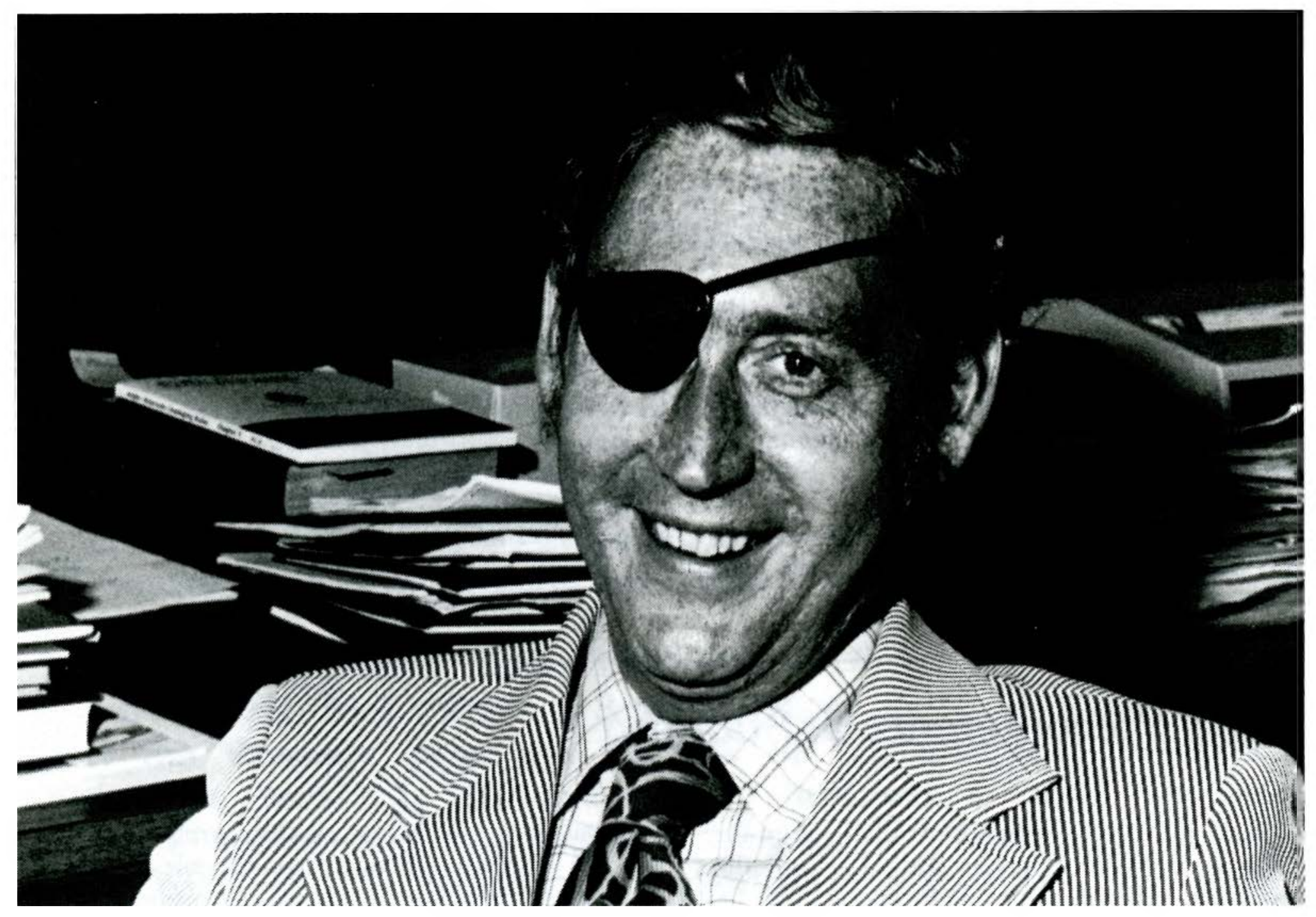

\title{
Hugh Atkinson Memorial Resolution
}

The following resolution was passed by the ACRL Board of Directors at the ALA Midwinter Meeting in honor of Hugh Atkinson (1933-1986), director of libraries at the University of Illinois, Urbana-Champaign, who passed away on October 24, 1986.

WHEREAS, Hugh Craig Atkinson distinguished himself in academic and research library leadership, and

WHEREAS, His ideas on the organization of academic libraries have significantly influenced academic and research librarians, and

WHEREAS, The impact of his leadership in the field of library automation has been felt by academic libraries of all sizes, and

WHEREAS, His contributions to cooperation among libraries of all types and sizes, in the State of
Illinois, nationwide, and internationally, are an inspiration to all, and

WHEREAS, His mentoring of individual academic and research librarians has enriched our profession immeasurably, and

WHEREAS, His untimely death on October 24 has diminished academic and research librarianship; NOW BE IT THEREFORE

RESOLVED, That the members of the Association of College and Research Libraries (American Library Association) recognize, express appreciation for, and call to mind the memory of Hugh Craig Atkinson for his outstanding contributions to the field of academic and research librarianship.

Adopted by the members and Board of Directors of the Association of College and Research Libraries, a division of the American Library Association, January 17, 1987, in Chicago, Illinois.

\section{8-89 Fulbright Scholar awards}

The Council for International Exchange of Scholars has announced the opening of competition for the 1988-89 Fulbright grants in research and university lecturing abroad.

The awards for 1988-89 include more than 300 grants in research and 700 grants in university lec- turing for periods ranging from three months to a full academic year. There are openings in over 100 countries and, in some instances, the opportunity for multi-country research is available. Fulbright Awards are granted in virtually all disciplines, and scholars in all academic ranks are eligible to apply. 
Applications are also encouraged from retired faculty and independent scholars.

Benefits include round-trip travel for the grantee and, for most full academic year awards, one dependent; maintenance allowance to cover living costs of grantee and family; tuition allowance, in many countries, for school-age children; and book and baggage allowances.

The basic eligibility requirements for a Fulbright Award are U.S. citizenship; Ph.D. or comparable professional qualifications; university or college teaching experience; and, for selected assignments, proficiency in a foreign language. A new policy removes the limit of two Fulbright grants to a single scholar.

Application deadlines for the Awards are: June 15, 1987 (for Australasia, India, and Latin Amer- ica, except lecturing awards to Mexico, Venezuela, and the Caribbean); September 15, 1987 (for Africa, Asia, Europe, the Middle East, and lecturing awards to Mexico, Venezuela, and the Caribbean); November 1, 1987 (for institutional proposals for the Scholar-in-Residence Program); January 1, 1988 (for Administrators' Awards in Germany, Japan, and the United Kingdom; the Seminar in German Civilization; the NATO Research Fellowships; and the Spain Research Fellowships); and February 1, 1988 (for the France, Italy, and Germany Travel-Only Awards).

For more information and applications, call or write the Council for International Exchange of Scholars, Eleven Dupont Circle, N.W., Washington, D.C. 20036-1257; (202) 939-5401.

\section{RBMS Preconference at Stanford}

"Reconsidering Libraries and Scholarship: Special Collections and New Directions in Humanities Research" is the theme of the Twenty-Eighth Preconference of the ACRL Rare Books and Manuscripts Section to be held June 23-26, 1987, at Stanford University. The papers will focus on the relationship between special collections and new directions in humanistic scholarship.

In recent years, scholars have broadened the conceptual boundaries of disciplines in the humanities, creating new fields of study and changing the nature of scholarly research. In this new setting, the role of traditional research materials such as rare books and manuscripts is being re-examined, and materials once considered outside the scope of learned research are increasingly at its center.

Program sessions of the Preconference will focus on the impact of the changing nature of scholarship in special collections. Topics will include presentations by scholars and librarians on their use of special collections, the nature and evolution of the concept of special collections in libraries, current research in bibliography, and the role of the special collections librarian in scholarly research.

Speakers and their topics include: W.B. Carnochan (Humanities Center, Stanford University) on recent trends in humanities scholarship; William L. Joyce (Princeton University Library) on the concept of special collections in libraries; Daniel $\mathrm{H}$. Traister (University of Pennsylvania Library) on the impact of changing attitudes toward the canon of accepted texts on rare book collection development; Jean E. Howard (English Department, Syracuse University) on libraries and new movements in scholarship, especially feminism; Paul Needham (Pierpont Morgan Library) on current scholarship in bibliography and related fields; Carl Degler (History Department, Stanford University) on re- cent developments in historical research; and Paul S. Koda (Catholic University) on the role of special collections librarians in humanistic research. Paul H. Mosher (Stanford University) and David H. Stam (Syracuse University) will summarize and reflect on the conference sessions.

The Preconference will open on Tuesday, June 23 , with a reception at Stanford University sponsored by the Northern California Chapter of the Antiquarian Booksellers Association of America. Additional receptions will be held on Thursday evening, June 25, at the offices of the Book Club of California and the California Historical Society.

Registration for the Preconference is limited to the first 250 applicants. The registration fee is $\$ 100$ for ACRL members and $\$ 140$ for non-members. The deadline for registration is May 15, 1987. Late registrations will be accepted on a space-available basis after May 15 at an additional cost of $\$ 15$ per person. Copies of the registration form can be obtained by writing to RBMS Preconference, ACRL/ALA, 50 E. Huron St., Chicago, IL 606112795.

Rooms will be available in the Stanford University dormitories. The rates, which include all meals except Thursday evening, are: single, $\$ 204.25$; double occupancy, $\$ 180.25$ per person. Suggestions for alternative housing may be requested when filling out the Preconference registration form.

Donald Farren is chair of the Rare Books and Manuscripts Section of ACRL. Members of the Preconference Program Committee are: Samuel A. Streit (chair), Pat Bozeman, Lynda Corey Claassen, Donald Farren, William L. Joyce, Daniel Traister, and Michael Ryan (chair, Local Arrangements). 
The Columbia University School of Library Service 1987 Rare Book School will run from July $6-31$ and will feature 24 five-day courses on various subjects of interest to research and rare book librarians. Class size will be limited; admission will be competitive. Tuition will be $\$ 400$ per course. Low-cost, a/c, on-campus housing will be available for about $\$ 30 /$ night.

Courses offered include The History of the Book (Alice D Schreyer/Peter

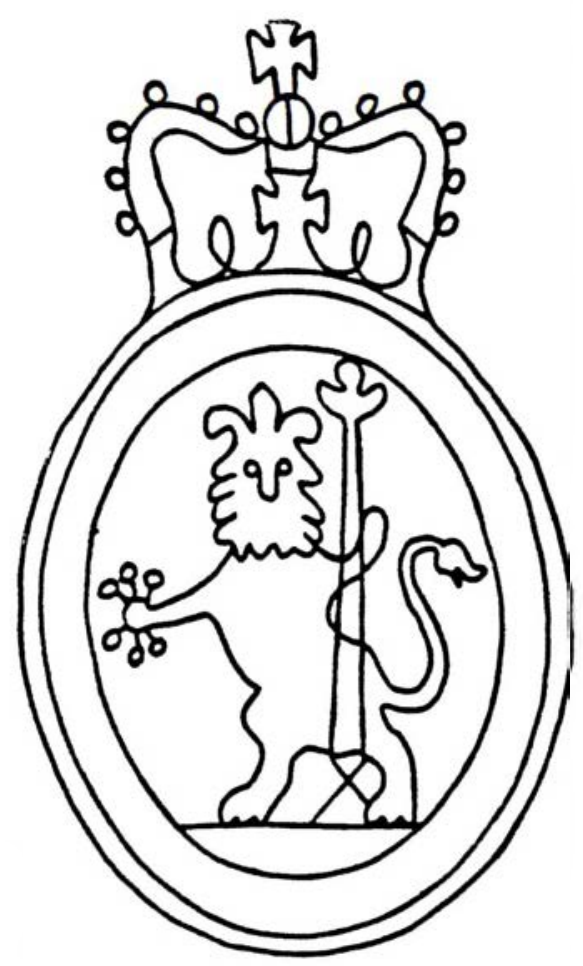
$M$ Van Wingen); Aims and Methods of Codicological Research (Albert Derolez); Introduction to Medieval \& Early Renaissance Bookbinding Structures (Christopher Clarkson); Topics in Medieval and Renaissance Bookbinding Structures (Christopher Clarkson); History of European and American Papermaking (Timothy D Barrett/John Bidwe11); Italian Humanistic Manuscripts of the c15 (Albinia de la Mare); Evidence of Ownership: Tools \& Techniques for Investigating the History of an Farly Printed Book (Nicolas Barker/Robin G Halwas); European Bookbinding 1500-1800 (Nicholas Pickwoad); Book Illustration to 1860 (Terry Belanger/Joan M Friedman); Rare Materials in Music, 1500-1900 (Jean Bowen/Susan T Sommer); History of the Book in America (Michael Winship; Western Americana (George A Miles/William S Reese); English and American Book Design 1886-1986 (Greer Allen/John Dreyfus); Introduction to Descriptive Bibliography (Terry Belanger/Donald Farren); Scholarly Editing (G Thomas Tanselle); Introduction to Rare Book Librarianship (John Parker/Daniel Traister); Strategies for Special Collections (Samuel A Streit/Merrily E Taylor); Rare Book Cataloging (Suzy Taraba/Stephen Young); Microcomputer Applications for Special Collections (Joan M Friedman); Curatorship of Non-Book and Museum Objects in Special Collections (E1len S Dunlap); Introduction to Photography Curatorship (Julia Van Haaften/James Reilly); Developing Collections of Fine Printing (D Steven Corey, with Francis 0 Mattson \& Claire Van Viet); Building 20th-century Literary Collections (Anthony Rota).

For more information and an application form, write to Rare Book School, Columbia University School of Library Service, New York, NY 10027; tel. 212/280-4734. 